\title{
Studies on the Characterization of Esterase from Different Pisum sativum L. (Fabaceae) Varieties
}

\author{
ANUSHREE SRINIVASA MURTHY ${ }^{1}$, RAMYA MANJUNATH', \\ TULASI DHONDALE PRAKASH ${ }^{1}$, MAHESH KRISHNA REDDY ${ }^{1}$, \\ KRISHNA RAO JAGARLAMUDI ${ }^{1}$, BALASUBRAMANIAN SATHYAMURTHY ${ }^{2 *}$, \\ GABRIELA TATARINGA ${ }^{3 *}$ \\ ${ }^{1}$ Ramaiah College of Arts, Science and Commerce, Department of Biochemistry, 560054 Bangaluru, Karnataka, India \\ ${ }^{2}$ Royale Concorde PU College, Department of Chemistry, Kalyan Nagar, 560054, Bangalore, India \\ ${ }^{3}$ Grigore T. Popa University of Medicine and Pharmacy Iasi, 16 Universitatii Str., 700115 Iasi, Romania
}

\begin{abstract}
Pisum sativum L. (Fabaceae) is important in diet due to its fiber content, protein, starch, trace elements and phytochemical substances. Dichlorvos (2, 3-dichlorovinyl dimethyl phosphate) is commonly known as organophosphates belong to the classes of insecticides that are used to control households and stored products insects. The aim of this study was to analyze the kinetic characteristics of esterase enzyme from four different varieties of Pisum sativum L. using qualitative and quantitative method and also the docking position of esterase with Dichlorvos by insilico method. According to our study the total activity was highest for Arka Nirmala and Arka Priya varieties. The specific activity was highest for Arka Mayur variety. Km and $V_{\max }$, were found to be higher for Arka Uttam. The optimum temperature and $\mathrm{pH}$ for all the varieties were found to be same, $40^{\circ} \mathrm{C}$ and 7.5 respectively. The inhibitor studies showed Arka Nirmala was more sensitive to inhibitor. From the fitness and interaction profile it was found that the inhibitor dichlorovos is an effective pesticide which can be used to inhibit esterase activity. It has one hydrogen bond of $H-S$ and had an amino acid residue at ARG57.
\end{abstract}

Keywords: Pisum sativum L., Esterase, Dichlorvos, Molecular Docking

\section{Introduction}

Medicinal plants are widely used to treat some disorders and to maintain a healthy state in both modern and traditional medicine [1]. It provides three main benefits: health benefits, financial benefits and society wide benefits. Pisum sativum L. (Fabaceae), as known as green pea or garden pea, is important in every day diet due to its fiber, protein, starch, trace elements and many phytochemical contents [2]. Many studies proved that it has antibacterial, antidiabetic, antifungal, anti-inflammatory, anti-hyper cholesterolemia, antioxidant and anticancer properties [2,3].

Plant esterases are involved in food spoilage. The significant functions of these esterases also include in metabolism and subsequent detoxification of many agrochemicals and pharmaceuticals $[4,5]$. Thus, the esterases catalyze the hydrolysis of aliphatic and aromatic esters and have been widely studied because of their metabolic functions, in flavor development and role in the breakdown of the insecticides [6].

Dichlorovos (2, 3-dichlorovinyldimethylphosphate) referred as organophosphates which belongs to insecticides. Therapeutically, dichlorovos is used as a fumigant and to treat a variety of parasitic worm infections in dogs, livestock and humans [7,8].

Using docking analysis the targeted protein (esterase) and the ligand (Dichlorovos) was conducted to analyze the fitness and the interaction with each other in the form of energy. This interaction could be used as the pharmaceutical approach for drug production $[9,10,11]$.

The aim of this study is to find the different kinetic characteristics of esterase and also the best fit between dichlorovos inhibitor and the esterase.

\footnotetext{
*email: balasramaiah@gmail.com; gtataringa22@yahoo.com
} 


\section{Materials and methods \\ Preparation of the enzyme extract}

Four varieties of Pisum sativum L. were used: Arka Mayur, Arka Nirmal, Arka Uttam and Arka Priya. $5 \mathrm{~g}$ of Pisum sativum L. (from GKVK, University of Agricultural Sciences, Bengaluru, India) were weighed and homogenized using mortar and pestle by adding $0.05 \mathrm{M}$ chilled phosphate buffer 100 $\mathrm{mL}(p \mathrm{H} \mathrm{=7)}$. The homogenate was centrifuged for $10 \mathrm{~min}$ at $10000 \mathrm{rpm}$ in a refrigerated centrifuge and was collected in beaker maintained at low temperature. The volume of the supernatant containing crude enzyme was measured.

For qualitative analysis, FC method and UV-VIS spectrophotometry was used: molybdenum in phosphomolybdate tungstate complex is reduced by tyrosine and tryptophan residues of protein to form blue color complex. Its blue color is enhanced by the presence of copper ions. The protein content obtained can be used for the determination of specific activity of esterase enzyme.

For quantitative analysis, different parameters such as total protein concentration, $K m$ and $\mathrm{V}_{\max }$, optimum $p \mathrm{H}$ and temperature, activation energy and specific activity were analyzed.

Total protein content was done using $25 \mathrm{~mL}$ of substrate and appropriate buffer and diluted enzyme was added and incubated for specific time period, the reaction was arrested by adding diazo blue lauryl sulphate (DBLS) reagent and absorbance was read at $600 \mathrm{~nm}$.

An inhibition study was carried by determining the esterase enzyme activity against different concentrations of dichlorvos $(0.2 \mathrm{mM}$ to $1 \mathrm{mM})$ as inhibitor.

\section{Estimation of the total activity of esterase}

Total activity of the enzyme is calculated at different time intervals and it is based on the reaction between substrate and enzyme. It is measured in terms of IU.

\section{Estimation of specific activity of esterase}

Specific activity gives a measurement of enzyme purity in the mixture. It is calculated by dividing the total activity with total protein and it is measured in terms of IU/mg.

\section{Estimation of $\mathbf{K m}$ and $V_{\text {max }}$}

$\mathrm{Km}$ is defined as the substrate concentration at velocity which is half from the final velocity that is Vmax. Different volumes of $0.3 \mathrm{mM}$ substrate solution was taken in different tubes and made up to $5 \mathrm{~mL}$ with $0.5 \mathrm{M}$ phosphate buffer $(p \mathrm{H}=7)$. Diluted enzyme $(1: 20)$ is taken and $1 \mathrm{~mL}$ is added to tubes at different time intervals and incubated for $15 \mathrm{~min}$. After this, DBLS is added and reaction is arrested and again incubated for $15 \mathrm{~min}$ for color development. $\mathrm{Km}$ and $V_{\max }$ are measured in terms of $\mathrm{mM}$ and $\mu \mathrm{m} /$ min respectively.

\section{Estimation of optimum pH}

Phosphate buffer, Citrate buffer and Tris buffer was added in different tubes along with $1 \mathrm{~mL}$ of enzyme and incubated for $1 \mathrm{~h} .0 .5 \mathrm{~mL}$ of substrate was added and again incubated for $20 \mathrm{~min}$; DBLS was added to arrest the reaction and again incubated for $20 \mathrm{~min}$.

\section{Estimation of Optimum temperature and activation energy}

To the substrate $(5.0 \mathrm{~mL}), 0.5 \mathrm{~mL}$ enzyme was added and incubated at different temperatures $20^{\circ}$, $25^{\circ}, 30^{\circ}, 40^{\circ}, 45^{\circ} \mathrm{C}$ for $20 \mathrm{~min}$. Reaction was arrested using DBLS. Then tubes were kept at room temperature for $15 \mathrm{~min}$. Absorbance was read at $600 \mathrm{~nm}$.

\section{Estimation of IC 50 value of the inhibitor}

IC is expressed as an inhibitor concentration at which $50 \%$ of the enzyme is inhibited.

To all tubes, $2.5 \mathrm{~mL}$ of different concentrations of inhibitor $(0.2 \mathrm{mM}, 0.4 \mathrm{mM}, 0.6 \mathrm{mM}, 0.8 \mathrm{mM}$ and $1 \mathrm{mM}$ ) and $0.5 \mathrm{~mL}$ of enzyme were added. The tubes were incubated at $10^{\circ} \mathrm{C}$ for $10 \mathrm{~min}$. Then $2.5 \mathrm{~mL}$ 
of different concentrations of substrate were added and incubated for $10 \mathrm{~min}$ at room temperature. The reaction was stop by adding $1 \mathrm{~mL}$ of DBLS. All the tubes were incubated for $15 \mathrm{~min}$ at room temperature. The absorbance was read at $600 \mathrm{~nm}$.

\section{In silico analysis}

The protein data bank (PDB) was used to obtain the three-dimensional structure of the macromolecule. The downloaded proteins were viewed in Py-Mol viewer (version 2.3.4) [12, 13]. Ligand (Dicholorvos), used for the study was constructed using ChemSketch. The constructed ligands were optimized to add the hydrogen bonds and the obtained structures were saved in mol for docking analysis. Docking studies were conducted using iGEMDOCK software [14]. The best binding pose, the binding affinity and the total binding energy values were saved in the output folder. The saved files were visualized in Py-Mol viewer [15,16].

\section{Results and discussions}

Protein concentration of the investigated extracts (4 samples) namely Arka Mayur, Arka Nirmala, Arka Priya and Arka Uttam was determined (Figure 1).

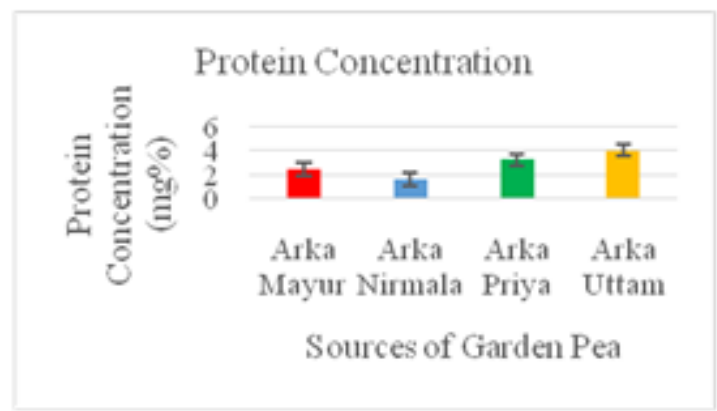

Figure 1. Protein concentration of samples

It was found that all four samples of Pisum sativum L. have different total protein content. Arka Uttam had the highest protein $(4.0 \mathrm{mg} \%$ extract) content in the extract, followed by Arka Priya (3.2 $\mathrm{mg}$ $\%)$, Arka Mayur (2.4mg \%) and Arka Nirmala (1.6mg \%). The concentration of the protein determines the quality of the Pisum sativum L. and it is strongly influenced by plant genetics and growing conditions [17].

\section{Estimation of the total activity of esterase}

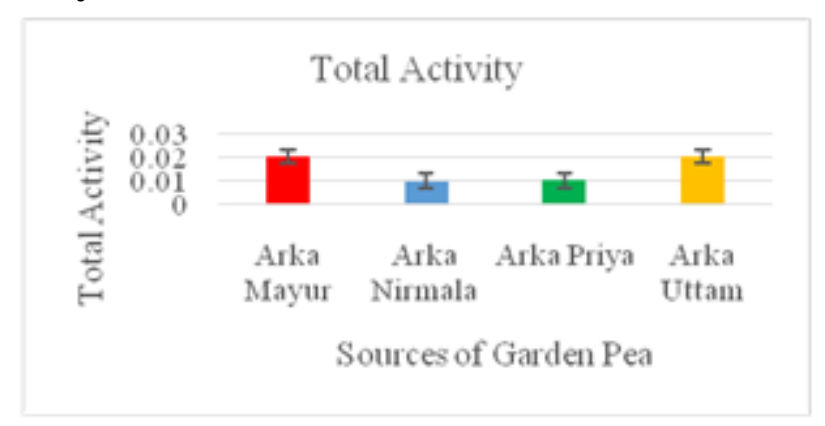

Figure 2. Total activity of enzymes

From Figure 2, it was found that all different varieties had various total activities for the same enzyme. Among four, Arka Nirmala and Arka Priya showed highest total activity of 0.10 IU, whereas Arka Uttam and Arka Mayur has very less total activity of 0.02 IU. More total activity determines the quality of the Pisum sativum L. and it is strongly influenced by many factors [17], 


\section{Estimation of specific activity of esterase}

Specific activities of esterase enzyme from four different sources were given in Figure 3. It was seen that all the varieties has almost near specific activities. But comparatively, Arka Mayur showed a slight highest specific activity of $0.008 \mathrm{IU} / \mathrm{mg}$, which was followed by Arka Nirmala (0.006 IU/mg), Arka Uttam $(0.005 \mathrm{IU} / \mathrm{mg})$ and Arka Priya $(0.003 \mathrm{IU} / \mathrm{mg})$. Specific activity will be more accurate than the total activity. More specific activity determines the amount of esterase present in the solution [18].

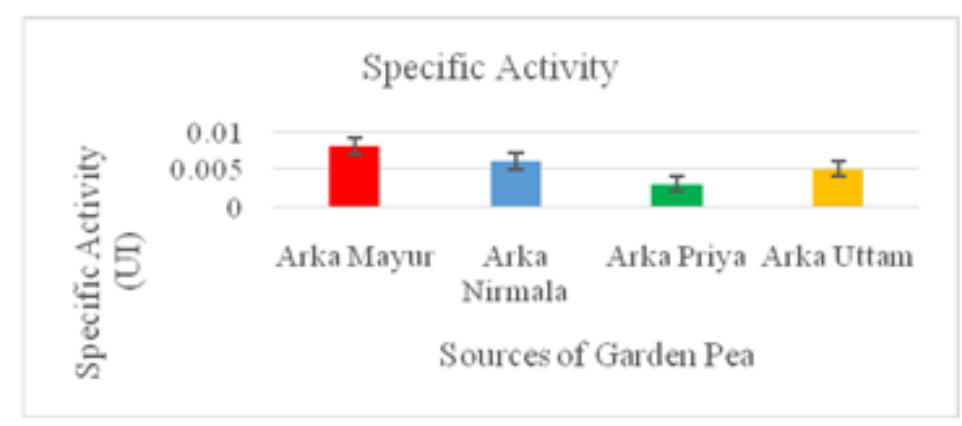

Figure 3. Specific Activity of Enzymes

\section{Estimation of $\mathbf{K m}$}

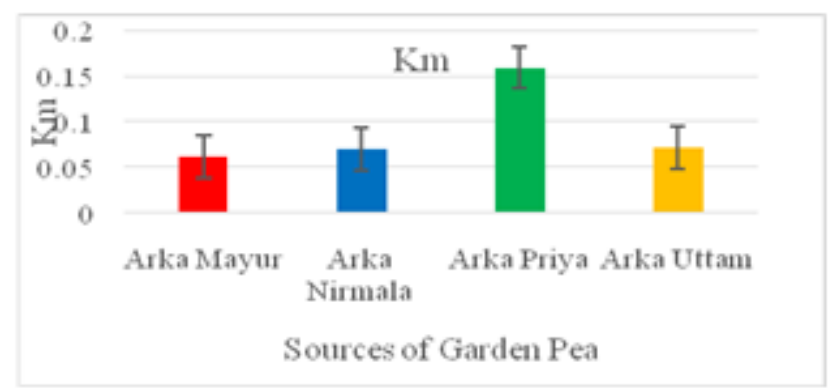

Figure 4. $K m$ value of esterase enzymes

Arka Priya was found to have the largest $K m$ value of $0.16 \mathrm{mM}$, whereas the other three varieties showed values like $0.062 \mathrm{mM}, 0.07 \mathrm{mM}$ and $0.072 \mathrm{mM}$ for Arka Mayur, Arka Nirmala and Arka Uttam respectively. Lower the $K m$ value higher the affinity of the enzyme and substrate. Hence the enzymes present in Arka Mayur shows the higher affinity towards the substrate [18].

\section{Estimation of $V_{\max }$}

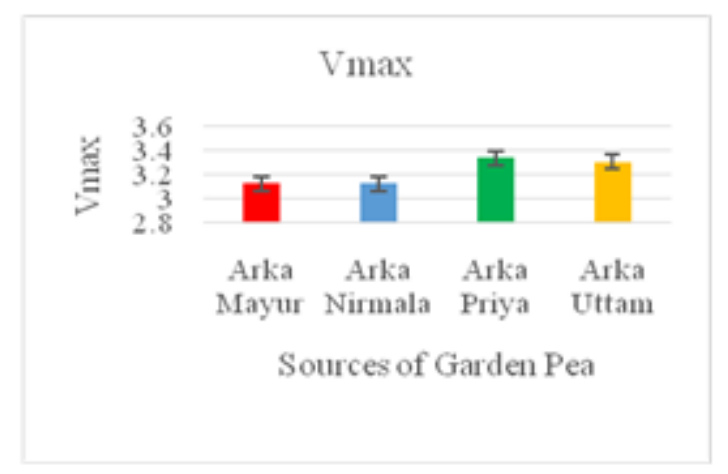

Figure 5.Vmax value of esterase 
From Figure 5, Arka Mayur and Arka Nirmala showed similar values of $3.12 \mu \mathrm{m} / \mathrm{min}$, and other two varieties like Arka Uttam and Arka Priya showed $3.33 \mu \mathrm{m} / \mathrm{min}$.

\section{Estimation of optimum $p \mathbf{H}$}

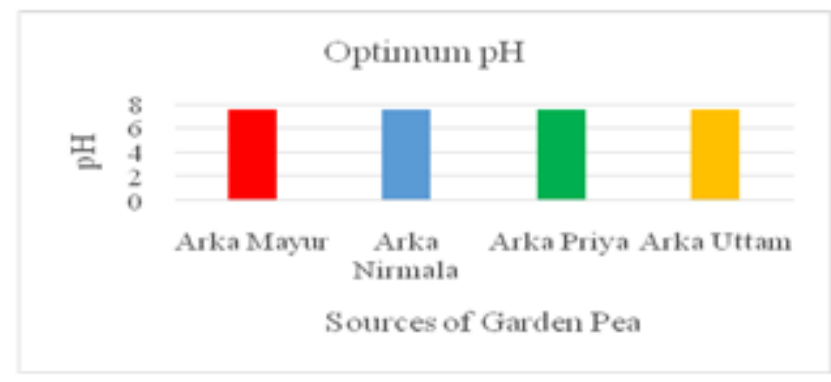

Figure 6.Optimum $p \mathrm{H}$ value of esterase

From Figure 6, the optimum $p \mathrm{H}$ for esterase enzyme in all four different samples was found out to be 7.5. The activity of the enzyme depends on $p \mathrm{H}$ of the solution. Most of the enzymes are active at neutral $p \mathrm{H}$ that is between $6.5-7.5$ [19].

\section{Estimation of Optimum temperature and activation energy}

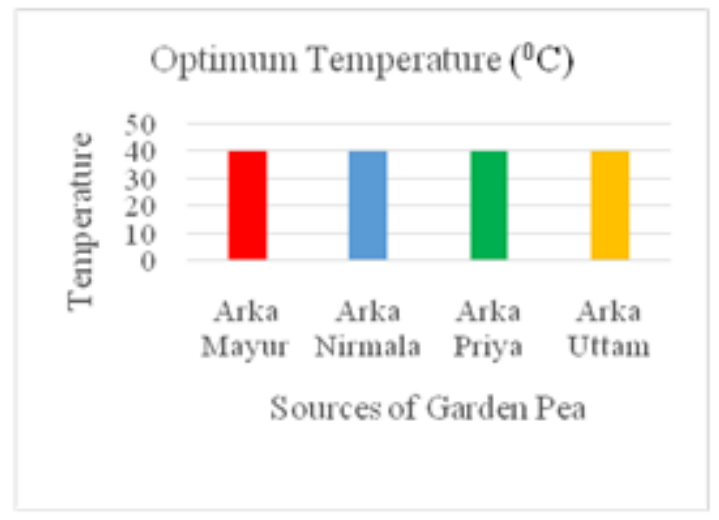

Figure 7. Optimum temperature of esterase enzymes

From Figure 7, the optimum temperature was found the same for all four samples. The optimum temperature of esterase enzyme for all four different varieties was $40^{\circ} \mathrm{C}$ [19].

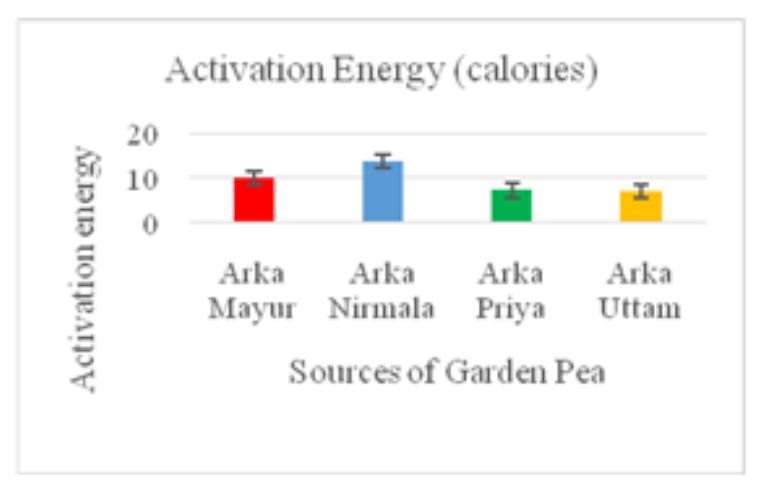

Figure 8. Activation energy ofesterase enzymes

From Figure 8, activation energies of esterase enzyme were found out for four samples of Pisum sativum. L. Among the four Arka Nirmala showed large activation energy of value 13.6 calories, 
preceded by Arka Mayur having 10 calories. Arka Uttam and Arka Priya had similar activation energies of 7.0 calories and 7.2 calories respectively. Lower the activation energy higher is its rate of reaction [18].

\section{Estimation of IC 50 value of the inhibitor}

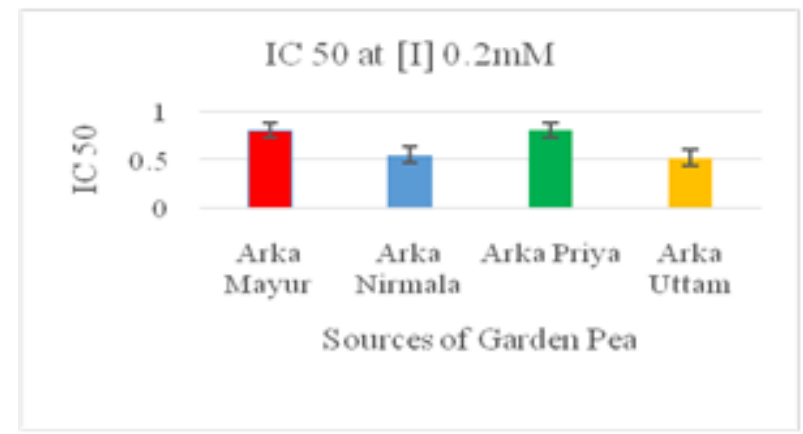

Figure 9. IC 50 values at [I] $0.2 \mathrm{mM}$

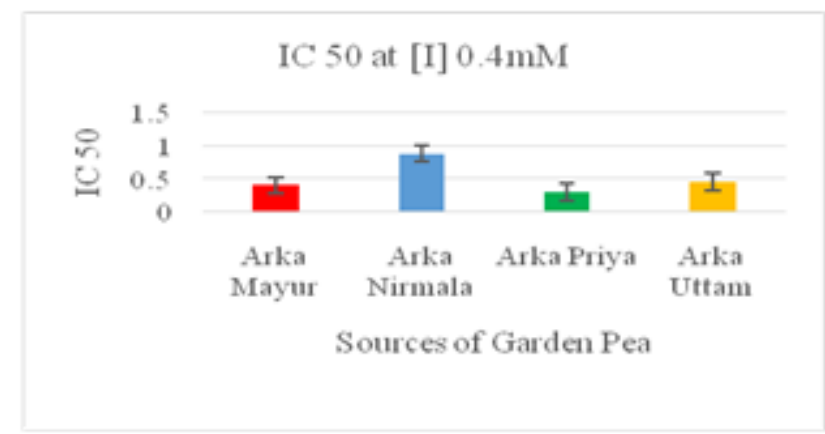

Figure 10. IC 50 values at $[\mathrm{I}] 0.4 \mathrm{mM}$

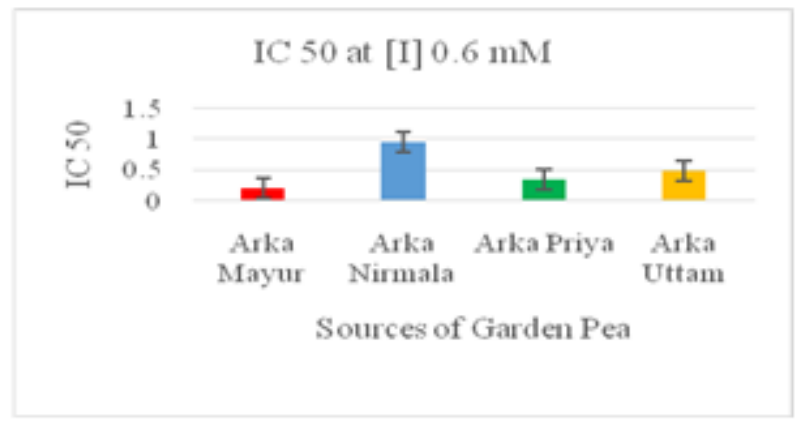

Figure 11. IC 50 values at $[\mathrm{I}] 0.4 \mathrm{Mm}$

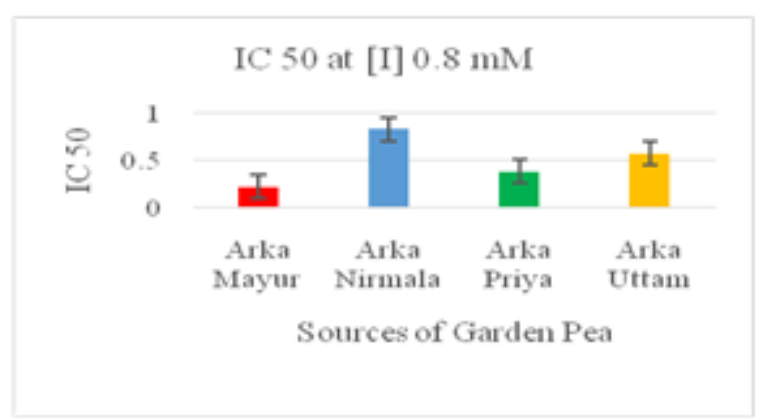

Figure 12. IC 50 values at $[\mathrm{I}] 0.8 \mathrm{mM}$ 


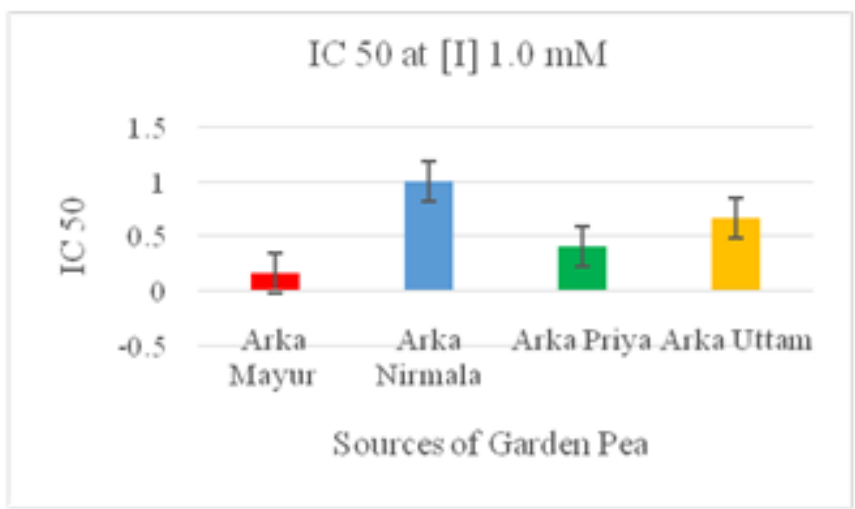

Figure 13. IC 50 values at $[\mathrm{I}] 0.8 \mathrm{mM}$

From Figures 9 - 13, IC50 (mM) value depends on inhibitor concentration also. Inhibitor was more effective in Arka Nirmala variety, which was maximally inhibited at $1.0 \mathrm{mM}$ inhibitor concentration which had IC50=1 value. Arka Mayur and Arka Priya extracted enzymes were inhibited at minimal concentration of $0.2 \mathrm{mM}$ maximally which gave IC 50 value of $0.8 \mathrm{mM}$. The Arka Uttam extracted enzyme was inhibited at $1.0 \mathrm{Mm}$ concentration which had 0.66 IC50 values.

Estimation of fitness and interaction of inhibitor with esterase:

Table 1. The fitness and interaction profile of inhibitor dichlorvoswith the esterase enzyme of Pisum sativum

\begin{tabular}{|c|c|}
\hline Interactions & Values \\
\hline Total binding Energy $(\mathrm{kcal} / \mathrm{mol})$ & -68.18 \\
\hline Vander Waal's force $(\mathrm{kcal} / \mathrm{mol})$ & -40.37 \\
\hline E pharma & -68.2 \\
\hline H-bond energy $(\mathrm{kcal} / \mathrm{mol})$ & -27.81 \\
\hline Electrostatic force $(\mathrm{kcal} / \mathrm{mol})$ & 0 \\
\hline H-bond & H-S \\
\hline Amino acid position & ARG 57 \\
\hline H-bond energy $(\mathrm{kcal} / \mathrm{mol})$ & -9.2 \\
\hline
\end{tabular}

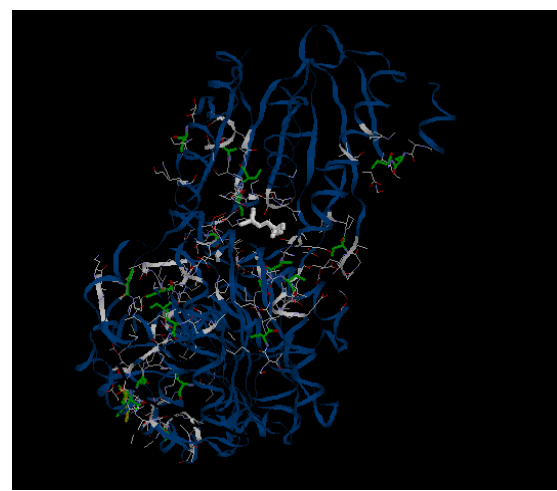

Figure 14. Interaction of dichlorvos with esterase enzyme

From Table 1 and Figure 14, the fitness and the interaction profile of inhibitor dichlorovos with esterase enzyme can be analyzed. It was found that the energy with which the inhibitor binds to esterase was around $-68.18 \mathrm{kcal} / \mathrm{mol}$. The Van der Wall's force of attraction between them was found to be as $40.37 \mathrm{kcal} / \mathrm{mol}$, but there was absence of electrostatic force of attraction. One amino acid, ARG $57 \mathrm{which}$ was present at the catalytic center was inhibited by dichlorovos. One hydrogen bond predominantly found (H-S bond) with the bond energy $-9.2 \mathrm{kcal} / \mathrm{mol}$. 


\section{Conclusions}

Among the four samples used for analysis, it was found that Arka Uttam variety had the highest concentration of protein approximately of about $4 \mathrm{mg}$ in $100 \mathrm{~mL}$ extract.

The total activity was similar in two samples, Arka Nirmala and Arka Priya, about 0.010 IU. But the specific activity was highest for Arka Mayur (0.08 IU/mg). Km and Vmax, the two kinetic characteristics, were found to be higher in Arka Uttam having the values of $0.072 \mathrm{mM}$ and $3.3 \mu \mathrm{m} / \mathrm{min}$ respectively. The optimum temperature and optimum $p \mathrm{H}$ for all the samples were found to be same, $40^{\circ} \mathrm{C}$ and 7.5 respectively. From the inhibitor studies it was found that, Arka Nirmala was more sensitive to Inhibitor at IC 50 levels. From the fitness and interaction profile it was found that the inhibitor dichlorovos is an effective pesticide which can be used to inhibit esterase activity. It has one hydrogen bond of $\mathrm{H}-\mathrm{S}$ and ARG57, an amino acid residue is present at the catalytic centre.

\section{References}

1.FIELD, C.B, et al.Science, 281(5374), 1998, p. 237.

2.SMITH-HALL, C. et al. J EthnobiolEthnomed, 8, 2012, p. 43.

3.RUNGRUANGMAITREE,R., JIRAUNGKOORSKUL, W. Pharmacogn. Rev., 11, no. 21, 2007, p. 39.

4.CHANDRE, M.A., BHAGYASHRI, N.R., CHAVAN, N.S., ASHOK, V., SHILPA, H., International Journal of Current Biotechnology, 2, no. 6, 2014, p.5.

5.BHAVITH, K.P., NARAYANA, S.M., RAMACHANDRASWAMY, N.,

CHANDRASHEKHARAIAH, K., Journal of Experimental Biology and Agricultural Sciences, 2, no.6, 2014, p.2320.

6.DEGRASSI, G., UOTILA, L., KLIMA, R., VENTURI, V., Applied And Environmental Microbiology, 65, no.8, 1999, p. 3470.

7.SUCHISMITA, D., Current World Environment, 8, no.1, 2013, p.143.

8.ABDU,I.T., LAWAN H. A., MODIBBO M.H., ABDULLAHI A.Y., The Journal Of Neurobehavioral Sciences, 3, no.1, 2016, p.7.

9.MEHMOOD, M.A., SEHAR, U., AHMAD, N., Journal ofData Mining in Genomics \&Proteomics, 5, no. 2, 2014, Article Number:1000158.

10.BERMAN, H.M., WESTBROOK, J., FENG, Z., GILLILAND, G., BHAT, T.N., WEISSIG, H., SHINDYALOV IN., BOURNE, P.E, Nucleic Acids Research, 28, no. 1, 2000, p. 235.

11.FERREIRA, L.G., RICARDO, N., OLIVA, G., ANDRICOPULO, A.D., Molecules, 20, 2015, p. 13384.

12.SUSHMITHA, H.S., BALASUBRAMANIAN, S., Indo American Journal of Pharmaceutical Sciences,5, no.8, 2018, p. 7784.

13.SUSHMITHA, H.S., BALASUBRAMANIAN, S., World Journal of Pharmaceutical Sciences, 6 , no. 9, 2018, p. 138.

14.SUSHMITHA, H. S., BALASUBRAMANIAN, S., European Journal of Biomedical and Pharmaceutical sciences, 5, no. 9, 2015, p. 520.

15.SUSHMITHA, H.S., BALASUBRAMANIAN, S., World Journal of Pharmaceutical and Life Sciences, 4, no. 9, 2018, p. 157 - 161

16.TATARINGA, G., BALASUBRAMANIAN, S., SANDU, I., ZBANCIOC, A.M., Rev.Chim., 70(9), $2019,3387$.

17.OLLE, M., Agronomy Research, 15, no.4, 2017, p. 1725-1732.

18.ROSSOMANDO, E F., Methods in Enzymology 182, 1990, p. 38-49

19.MAHESH, C., TARTE, S., ASHOK, K., NILESH, C., Asian Journal of Biochemical and Pharmaceutical Research, 4, no.3, 2014, p. 335 - 341.

$\overline{\text { Manuscript received: } 11.01 .2020}$ 